\title{
PENGARUH PERSENTASE SERAT NANAS TERHADAP KUAT TEKAN FOAMED CONCRETE
}

\author{
Teddy Irawan \\ Konsultan Design CV. Jasqi Palembang Sumatera Selatan \\ Jl. Musi VI Blok T No.32, Wayhitam, Siring Agung, Palembang \\ E-mail : teddyir54@gmail.com
}

\begin{abstract}
ABSTRAK
Foamed concrete diklasifikasikan kedalam beton ringan yang memiliki berat jenis $300-1.800 \mathrm{~kg} / \mathrm{m}^{3}$. Berat jenis foamed concrete yang ringan berpengaruh pada kekuatan beton. Foamed concrete dibuat dengan ditambahkan gelembung udara kedalam beton. Gelembung udara dibuat dengan foaming agent, semakin banyak foam yang dimasukkan kedalam beton maka semakin banyak pori yang terbentuk didalam beton sehingga menyebabkan kuat tekan menurun sehingga mempengaruhi berat jenis beton. Kekuatan beton dapat ditambah dengan serat nanas dan serat polypropylene yang memiliki kuat tarik yang tinggi. Persentase serat nanas dan serat polypropylene yang digunakan 0\%, 0,2\%, 0,4\% dari total berat volume dan dengan panjang serat $10 \mathrm{~mm}$. Berdasarkan hasil pengujian menunjukan nilai kuat tekan maksimum dengan persentase 0,4\% serat nanas sebesar 4,41 MPa (FCNO,4-10) dan minimum terdapat pada campuran dengan 0\% serat sebesar 2,85 MPa. Dari hasil penelitian terjadi peningkatkan kuat tekan foamed concrete dengan ditambahnya serat nanas.
\end{abstract}

Kata Kunci : Foamed concrete, Foaming Agent, Serat Nanas, Kuat tekan

\section{PENDAHULUAN}

Beton ringan memiliki berat jenis yang lebih ringan dibandingkan beton normal, pada umumnya beton ringan memiliki berat jenis $300-1.800 \mathrm{~kg} / \mathrm{m}^{3}$ (Awang, 2014). Foam concrete diklasifikasikan kedalam beton ringan yang dibuat dengan menambahkan gelembung udara kedalam beton dan bergantung pada banyaknya foam yang dimasukan kedalam campuran. Adanya gelembung udara, maka beton tersebut memiliki berat jenis yang ringan sehingga mempengaruhi kekuatan beton dikarenakan ikatan antar matrik semakin lemah.

Kelebihan foam concrete digunakan untuk dinding dengan tujuan mengurangi berat bangunan. Namun dalam penggunaan foamed concrete masih terbatas pada non struktural. Selain itu, kuat tekan dan kuat lentur dari beton ringan masih cukup rendah. Atas dasar hal tersebut maka penelitian ini dilakukan dengan inovasi penggunaan material pengganti semen berupa fly ash.

Foamed concrete memiliki berat jenis yang ringan. Namun dengan ringannya berat jenis foamed concrete dapat menyebabkan retak pada beton. Perkembangan teknologi dengan menggunakan tambahan serat alami dan serat buatan banyak dilakukan untuk memperbaiki retak pada foamed concrete. Selain itu, serat alami juga memiliki sifat terbarukan dan juga memiliki nilai ekonomis karena murah dan juga bermanfaat bagi lingkungan dan mengurangi limbah pertanian (Zakaria, 2015). Salah satu serat alami berasal dari tumbuhan yaitu serat nanas yang memiliki penyebaran luas yang dapat 
ditemukan pada daerah tropik dan subtropik. Serat nanas berasal dari daun nanas dan memiliki ketersediaan yang melimpah sehingga bisa dimanfaatkan untuk foamed concrete.

Berdasarkan uraian diatas, dilakukan penelitian mengenai foamed concrete dengan tambahan serat nanas judul Pengaruh Serat Nanas Terhadap Kuat Tekan Beton

\section{TINJAUAN PUSTAKA}

Beton ringan (lightweight concrete) adalah beton memiliki berat jenis yang lebih ringan dibandingkan beton normal, pada umumnya beton ringan memiliki berat jenis 300 - $1.800 \mathrm{~kg} / \mathrm{m}^{3}$ (Awang, 2014). Beton dapat dibuat ringan dengan beberapa cara, mengganti agregat kasar dengan agregat yang lebih ringan, dengan memasukkan gelembung udara kedalam beton, dengan beton non pasir (Sheety, 2000).

Menurut Moon et al. (2015), aerated concrete atau yang dikenal juga dengan cellular concrete dibagi menjadi tiga tipe yaitu: Autoclaved Aerated Concrete (AAC), Non Autoclave Concrete (NAAC), Foamed Concrete (NAAC).

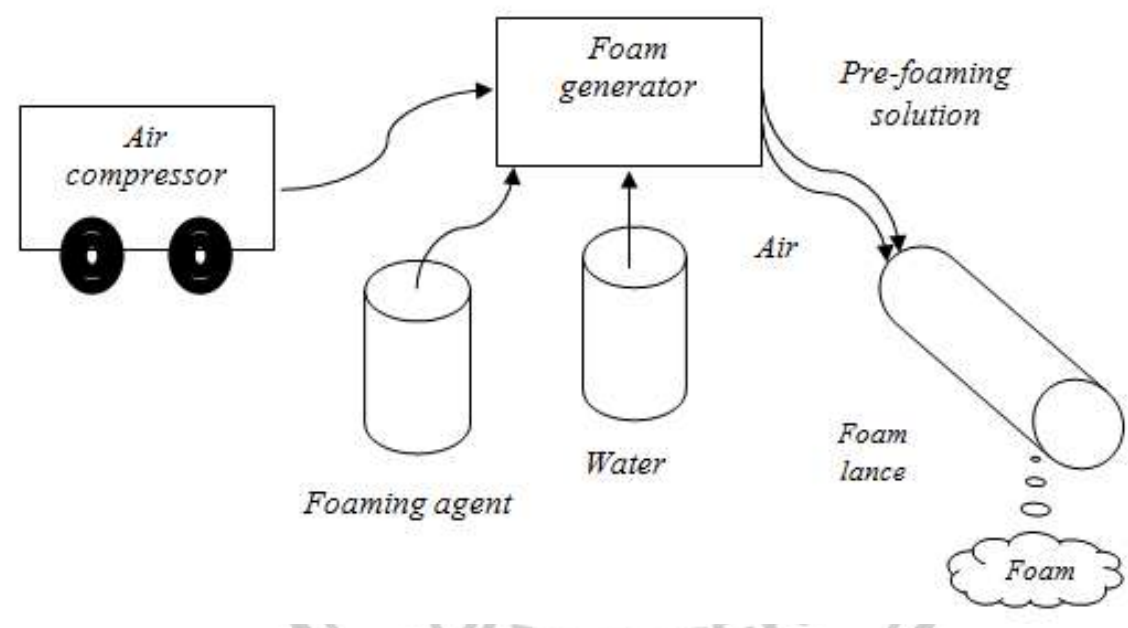

Gambar 1. Pembuatan foam dengan foaming agent (Hilal, 2015)

Menurut Onprom (2015), foam diproduksi dari foaming agent dengan dilarutkan kedalam air dengan perbandingan 1 : 30 dari volume dan foam memiliki berat jenis 50 $\mathrm{kg} / \mathrm{m}^{3}$. Menurut Hilal (2015), proses pembuatan Foam untuk foamed concrete dapat dilihat pada Gambar 1. menjelaskan proses pembuatan foam dengan foaming agent ditambahkan kedalam air maka menghasilkan gelembung berongga pada campuran pasta semen. Sifat foamed concrete sangat tergantung pada kualitas busa. Kegunaan beton ringan sebagai dinding dengan campuran sand dan quary dust dan ditambah dengan al powder dan dibandingkan dengan campuran yang tidak diberi al powder maka kuat tekannya mengalami penurunan akibat adanya meningkatnya al powder di dalam foam concrete. Aluminium powder yang berfungsi sebagai foaming agent membentuk gelembung udara pada beton. Aluminium powder dimasukan sekitar 0,2\%-0,5\% dari berat semen. Bahan baku yang baik untuk beton Autoclaved aerated concrete adalah bahan halus seperti silika, pasir kuarsa, kapur, semen dan bubuk aluminium (Hamad, 2014). 


\section{METODELOGI PENELITIAN}

Tahapan penelitian yang dilakukan di laboratorium adalah pengujian material pasir, fly ash, pengujian serat nanas, treatment serat nanas dan pemotongan serat nanas, perencanaan campuran foam concrete, pengadukan campuran foamed concrete.

Tahapan berikutnya pengujian slump flow, pengujian setting time, pencetakan benda uji, perawatan benda uji. Pengujian berat jenis, pengujian kuat tekan dengan benda uji silinder diameter $100 \mathrm{~mm}$ x $200 \mathrm{~mm}$ umur foam concrete 28 hari. Campuran foamed concrete berdasarkan ACI 523.3R-3.

Tabel 1. Rasio komposisi foamed concrete (berdasarkan volume, $\mathrm{m}^{3}$ )

\begin{tabular}{cccccccc}
\hline $\begin{array}{c}\text { Kode } \\
\text { Komposisi }\end{array}$ & $\begin{array}{c}\text { Persentase } \\
\text { serat } \\
(\%)\end{array}$ & $\begin{array}{c}\text { Panjang } \\
\text { serat } \\
(\mathrm{mm})\end{array}$ & $\begin{array}{c}\text { Semen } \\
(\mathrm{kg})\end{array}$ & $\begin{array}{c}\text { Fly } \\
\text { ash } \\
(\mathrm{kg})\end{array}$ & $\begin{array}{c}\text { Pasir } \\
(\mathrm{kg})\end{array}$ & $\begin{array}{c}\text { Foam } \\
(\text { liter })\end{array}$ & $\begin{array}{c}\text { Air } \\
(\text { liter })\end{array}$ \\
\hline FC0-0 & 0 & 0 & 408,05 & 45,34 & 453,39 & 500 & 204,02 \\
FCN0,2-10 & 0,2 & 10 & 408,05 & 45,34 & 453,39 & 500 & 204,02 \\
FCN0,4-10 & 0,4 & 10 & 408,05 & 45,34 & 453,39 & 500 & 204,02 \\
\hline
\end{tabular}

\section{HASIL DAN ANALISIS}

Berdasarkan Gambar 2 menunjukkan nilai kuat tekan minimum terdapat pada campuran FC0-0 dengan persentase 0\% serat sebesar 2,85 MPa. Campuran FCN0,2-10 menunjukan kuat tekan sebesar 4,36 MPa.Campuran FCN0,4-10 menunjukan kuat tekan maksimum sebesar 4,41MPa.

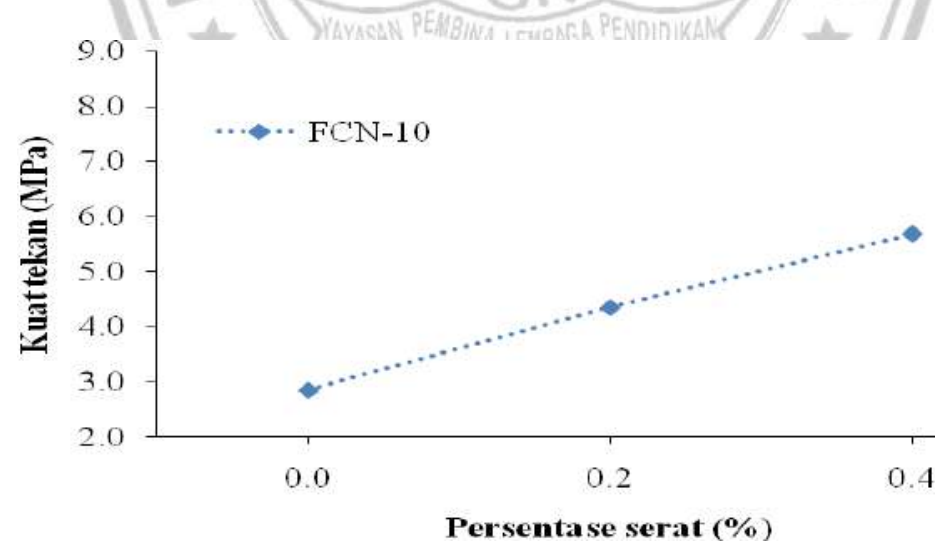

Gambar 2. Pengaruh persentase serat nanas terhadap kuat tekan pada umur 28 hari

\section{KESIMPULAN}

Hasil pengujian kuat tekan berdasarkan persentase serat nanas $0 \%, 0,2 \%$, dan $0,4 \%$ dengan panjang serat nanas $10 \mathrm{~mm}$, menunjukan nilai kuat tekan maksimum dengan persentase $0,4 \%$ serat nanas sebesar 4,41 MPa (FCN0,4-10) dan minimum terdapat pada campuran dengan $0 \%$ serat sebesar $2,85 \mathrm{MPa}$. Adanya peningkatan nilai kuat tekan beton seiring dengan bertambahnya persentase serat nanas. 


\section{DAFTAR PUSTAKA}

ACI 523.3R-93, 1993. Guide for Cellullar Concretes Above 50 pcf, and for Aggregate Concretes Above 50 pcf with Conpressive Strengths Less Than 2500 psi. ACI Committee 523, USA: American Concrete Institute.

Awang, Hanizam., Ahmad, Muhammad Hafiz. (2014). "Durability Properties of Foamed Concrete With Fiber Inclusion". International Journal of Civil, Environmental, Structural, Construction and Architectural Engineering Vol:8, No:3, 2014

Hamad, Ali J., (2014) "Material, Production, Properties and Application of Aerated Lightweight Concrete: Review". International Journal of Material Sciences and Engineering.

Hilal, Ameer A., Properties and Microstructure of Pre-formed Foamed Concretes, PhD thesis, University of Nottingham., 2015. United Kingdom.

Moon, Mr. Ashish S., Varghese, Valsoon \& Waghmare, S.S (2015) " Foam Concrete Can Be Used for Sustainable Construction as a Building Material". International Journal for Scientific Reseach \& Development.

Mydin Md Azree Othuman \& Roosli, Ruhizal. (2012) "Prediction of Elevated Temperature Flexural Strength of Lighweight Foamed Concrete Strengthened with Polypropylene Fibre and Fly Ash ". ISSN : 2222-1719

Onprom, Patchara Krit Chaimoon, and Raungrut Cheerarot. (2015) "Influence of Bottom Ash Replacements as Fine Aggregate on the Property of Cellular Concrete with Various Foam Contents". Thailand.

Sheety M.S., (2000) “Concrete Techonology”. S. Chad \& Company LTD. New Delhi - 110055

Zakaria, Noor Zawati., Suleiman, Mohd Zailan., \& Talib, Roslan (2015) "Turning Natural Fiber Reinforced Cement Composite as Innovative Alternative Sustainable Construction Material: A Review Paper". International Journal of Advanced Reseach. 